\section{HSE}

Historia Social y de la Educación

Social and Education History
Hipatia Press

www.hipatiapress.com

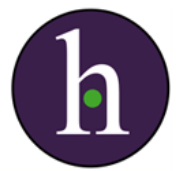

Instructions for authors, subscriptions and further details:

$\underline{\text { http://hse.hipatiapress.com }}$

\title{
Affirmative action: an overview of the history of resistance, struggle and achievements of the black population in the Brazilian context
}

Daniela Mara Gouvêa Bellini ${ }^{1}$, Francisca de Lima Constantino ${ }^{1}$

1) Universidade Federal de São Carlos (Brazil).

Date of publication: February $23^{\text {rd }}, 2016$

Edition period: February 2016 - June2016

To cite this article: Gouvêa, D.M. \& de Lima, F. (2016). Affirmative action: an overview of the history of resistance, struggle and achievements of the black population in the Brazilian context. Social and Education History 5(1), 1-25. doi:10.17583/hse.2016.1715

To link this article: http://dx.doi.org/10.17583/hse.2016.1715

\section{PLEASE SCROLL DOWN FOR ARTICLE}

The terms and conditions of use are related to the Open Journal System and to Creative Commons Attribution License (CC-BY). 


\section{Affirmative Action: an Overview of History of Resistance, Struggle and Achievements of the Black Population in the Brazilian Context}

Daniela Mara Gouvêa Bellini

Universidade Federal de São Carlos

(Brazil)
Francisca de Lima Constantino

Universidade Federal de São Carlos

(Brazil)

\section{Abstract}

This article seeks to present a reflection on affirmative actions that are characterized as public policies aimed at minority groups. On this perspective, we will make a cutting in the racial inequalities between blacks and whites in the Brazilian context, for the disparities between these groups are not marked only by social class, but also by the ambiguous racism that prevails in the country. Thereby, we seek to make the complaint of racial inequality in Brazil, as well as the announcement of answers achieved by the struggle of the black population, personified on the black movement and in actions in favor of black men and women who historically lived on the margins of society. In this sense, we organized the paper into three parts, plus the introduction and closing remarks. First, we present a brief historical and social context of race relations in Brazil. Then, we speak of about the steps and achievements of the black movement in the country. Finally, we highlight the affirmative action adopted for the benefit of black people, especially in the educational field, like the quota system in universities.

Keywords: affirmative action, black movement, education, Brazil 


\section{Acciones Afirmativas: un Panorama de la Historia de Resistencias, Lucha y Conquista de la Población Negra en el Contexto Brasileño}

Daniela Mara Gouvêa Bellini

Universidade Federal de São Carlos

(Brazil)
Francisca de Lima Constantino

Universidade Federal de São Carlos

(Brazil)

\section{Resumen}

Ese artículo presenta una reflexión sobre las acciones afirmativas que se caracterizan como políticas públicas dirigidas a grupos minoritarios. Desde esta perspectiva, se focalizarán las desigualdades raciales entre negros y blancos en el contexto brasileño, pues las disparidades entre estos grupos no están marcadas solamente por la clase social, sino también por el racismo ambiguo que prevalece en el país. Así, denunciamos a la desigualdad racial en Brazil, bien como buscamos hacer el anuncio de respuestas alcanzadas por la lucha de la población negra, personificada en el movimiento negro y en acciones ya logradas en favor de las mujeres y hombres negros. En este sentido, hemos organizado el trabajo en tres partes, además de la introducción y las consideraciones finales. En primer lugar se presenta un breve contexto histórico y social de las relaciones raciales en Brasil. Luego seguimos los pasos y logros del movimiento negro en el país. Por último, destacamos a las políticas de acción afirmativa adoptadas en beneficio de la gente negra, especialmente el sistema de cuotas en las universidades en cuanto campo de la igualdad educativa.

Palabras clave: acción afirmativa, movimiento negro, educación, Brasil. 
W hen we talk about affirmative action we must first understand what it means, in what context such actions were taken and who they benefited or benefit. Based on Piovisan (2005) certain subjects of rights or certain violations of law require a specific and differentiated response because there are certain groups that require special and specific protection in the face of their own vulnerability.

From this perspective, Piovisan (2005) points out that affirmative action can be seen as a powerful instrument of social inclusion, as it constitutes special and temporary measures to remedy a discriminatory past, this way, "affirmative action aims to speed up the process with the scope of substantive equality for vulnerable groups, such as ethnic and racial minorities and women, among other groups" (Piovisan, 2005, p.49).

Based on the National Curriculum Guidelines for the Education of Racial-Ethnic Relations (Brasil, 2004a), affirmative actions are characterized as repairs and recognition policies in response to racial $^{1}$ and social inequalities experienced by minority groups (blacks, indigenous, women, and children).

Women theorists and men theorists like Moehleck (2002), Maio and Santos (2009), Gomes (2009) point out in their study that throughout the 1970s, 1980s and 1990s, the black movement, as well as other social movements gained strength after a period of dictatorship with the country's democratization process. Based on the cited authors significant facts took place for the understanding of the changes and achievements gained in favor of the black population during these periods, which are: the promulgation of the 1988 Constitution; the Zumbi March of 1995; the approval of the Guidelines and Bases Law 9394/1996 (Brasil, 2004b); the Preparatory Regional Seminars for the World Conference Against Racism, Racial Discrimination, Xenophobia and Related Intolerance, the Third World UN Conference against Racism, Racial Discrimination, Xenophobia and Related Intolerance, held by the United Nations (UN) in Durban, South Africa in 2001 and, finally, the approval of the amendment of the Guidelines and Framework Law (LDB), Law 9394/96 by Law 10,639/2003 (Brasil, 2004a).

Such events, each in its own time boosted ways and measures that enabled not only a debate on racial inequalities but also the recognition of 
Brazilian racism, and the need for public policies in favor of historically marginalized populations in our country (black and indigenous) ${ }^{2}$.

Based on Gomes (2009), Brazil stands out for being one of the largest multiracial societies in the world and host a significant number of Africans dispersed in the Diaspora, however, this fact does not relieves the country of being racist, where prejudice and racial discrimination are marked with a past history of centuries of slavery ${ }^{3}$; the myth of racial democracy, the idea that blacks and whites ${ }^{4}$ live harmoniously, and an ambiguous racism that occurs not only because of an ethnic belonging expressed in the life, customs, traditions and history of the black population, but by the junction of this membership with the presence of diacritical marks, inscribed in the body (Gomes, 2008).

From this perspective, we seek to present some reflections on the adoption of affirmative action in a society marked not only by social, but also racial inequalities. The paper is organized into three sections, as well as the introduction and final considerations. In the first section, we present a brief overview of race relations in Brazil based in the context of historical and social transformations that the country has suffered from the colonial period to the present day. Then we dedicated ourselves to the Black Movement, by understanding that this, like other social movements, played and plays an important role across the achievements of the black population in Brazil. In the third section we reflect on the importance of affirmative action in the country, the impact of adopting this measure for the black population, and the current debate and the challenges posed to those who fight for a more equitable society.

The methodology for collection, election and usage of the basic texts to perform the historical review of the role of the black movement in Brazil considered productions of intellectuals and experts on the subject, who are also involved in some way with the movement. As for the government documents cited and analyzed, as well as being produced by the black movement itself, these pieces of legislation have a direct impact on public policies and the life of the black and white population. In editing the text, we followed the chronological order of facts and of laws and regulations. 


\section{HSE - Social and Education History, 5(1) 5}

\section{Race Relations in Brazil: from Past to Present}

As previously mentioned, Brazil is one of the largest multiracial societies in the world. However, it does not mean that the Brazilian people live in fact a racial democracy in which its population, especially blacks, whites and indigenous, is out of racial tensions. As we return our gaze back to the past of Brazilian history, and its relationship with the Africans and their descendants, we will come across a history of dehumanization of the African population, which until today has remnants that directly interfere in the lives of the black population and the relations between blacks and whites.

As Munanga and Gomes (2006) explain, the slave regime made Brazil a kind of society divided and organized into two unequal parts: the first consists of free women and men, the other for enslaved women and men the first white and the second black. This social division ended in benefits for the first group and disadvantages for the second, which carries with it the daily struggle to reframe its history.

Based on the studies of Ianni (2004), Munanga and Gomes (2006), slavery was the means that the Portuguese found to get the most profit from Brazil. Slave labor was the basis of the Brazilian economy until the midnineteenth century, first with the production of sugar and gradually the exploitation of other branches of agriculture such as cotton and coffee, and mining activities. As the authors and the author mentioned, the process of slavery in Brazil was dehumanizing and cruel, it transformed men and women, free in their land, into commodities, seen as objects and taking them to the loss of their identity.

Free beings in their native land, here were stripped of their humanity through a status that made them only animal workforce, things, goods or objects that could be bought and sold; sources of wealth for traffickers (sellers) and investments in "animal machines" work for buyers (planters) (Munanga \& Gomes, 2006, p.16).

Thus, Africans had to learn ways of survival and struggle to escape the physical, emotional and psychological imprisonment to which they were subjected. Many women commit abortions to rid their children of slavery, there were breakouts and murders to escape their subhuman way of living. 
And contrary to what we learned in school, Africans and their descendants have never accepted peacefully slave labor to which they were forced to carry out with no right to remuneration and decent life, thus sought strategies to resist and escape ill-treatment to which they were subdued.

Based on Ianni (2004), exploitation of compulsory labor, particularly slave labor, was subject to the movements of European commercial capital, which started to have other economic interests with the expansion of capitalism. Thus, from the second half of the nineteenth century, the economic and social structure of Brazil is profoundly modified and replaced by a less agricultural character and more commercial, less rural and more urban.

In this new context, the slave became a moot effective element; the slave regime ceases to be a beneficial deal (Ianni, 2004). To meet the new social, economic and political interests emerging in society in the mid nineteenth century, blacks find themselves officially "free" after three centuries of slavery. On May 13, 1888, the abolition of slavery is enacted. However, authors such as Maciel (1985) and Cunha Junior (2008) indicate that this freedom does not actually occurred; they explain that slavery remained for years, if not in practice, at least in people's thinking, i.e. now free blacks continued to receive the same treatment they used to have when they were in a condition of enslaved people. Moreover, Cunha Junior explains that by being freed blacks did not receive any attention from the government, there was no integration policy of this population to society and they were left out, as indicated by Maciel, losing their workplace.

As they were converted into citizens, the blacks met in a brutal way the alienated condition of freedom that was offered to them. The Brazilian society left the blacks to their own destiny, laying on their shoulders the responsibility to re-educate and transform themselves to meet the new standards and ideas of man, created by the advent of free labor, the republican regime and capitalism (Ianni, 2004, p.307).

In this way, the black population is at the same time "free and imprisoned," trapped in a past of dehumanization and abandoned to their fate, without housing, education, health and work, basic rights to human life. 
According to Ianni (2004), in 1889 and 1891, the Republican government gave orders to collect and burn the documentation on slavery, as erasing the data was a way to hide the facts. In addition, not asking about people's color in the census, for some years, meant a secondary factor of history erasure, or yet had no significance as a social fact. According to Ianni (2004), burning the records on slavery and not asking who were the blacks in the country, made the mobilization of the black population difficult, who did not know how many they were, where they lived and how they participated in the income and culture, which was very convenient to the white elite.

These actions were part of the political project of the Brazilian government, which wanted to make society white. The ideal of whitening was born in the post-abolition, based on scientific racism, which justified these and other atrocities against the black people, through the belief that the whites had a superiority, and that their blood (white) could purify African blood, considered "primitive", and so it would constitute a gradually "white and civilized" society (Oliveira, 2008).

According to the studies of Domingues (2002) and Oliveira (2008), the whitening policy was an action of promoting the self-denial of the black subject, for this subject starts desiring a white ideal, once that socially the beautiful and desirable is white, which leads to this policy a sense of white superiority and a sense of inferiority of the black. In this sense, we need to understand the complexity that permeates not only race relations between blacks and whites in the country but also the constitution of the self of these subjects.

The whitening ideology preached the integration of blacks via assimilation of white values and aimed to spread that there were no racial differences in Brazil and all lived here in harmony without conflicts (Oliveira, 2008, p.6).

In this perspective, Munanga (2006) explains:

In the construction of Brazil's racial system, the mestizo is seen as a transcendent bridge, where the white-black-indigenous triad is and dissolves into a common category founding of nationality. Hence the myth of racial democracy: we were mixed in the origin and 
today we are neither black or white, but a mixed-race people, a mongrel people (Munanga, 2006, p.131).

However, such thinking does not apply to practice because when we talk about equity there is a big gap between blacks and whites. The racial democracy myth serves only as a complicating factor in race relations in Brazil, as it hangs over the Brazilian society this idea that blacks and whites live harmoniously without conflicts and tensions. However, reality shows us that race relations in the country are stressed by racism and that skin color is a social marker that restricts social equality for blacks.

Brazilian society, through the myth of racial democracy, lives under a tangle of acceptance and rejection of ideas in relation to blacks. "This ambiguous behavior inhibits the debate on social rights of the black population, including the right of not being discriminated" (Santos, 2009, p.25). In addition, there is also the ambiguity between color and class, which thanks to the myth of racial democracy, permeates the idea of many Brazilians: the most important discrimination in Brazil would be social and not racial (Munanga, 2006). In this sense, the myth of racial democracy "is a fallacy to cover existing racist practices in the country, and exempt the white group of a reflection on itself" (Cavalleiro, 2000 p. 29).

From this perspective, we must consider that inequalities between blacks and whites go beyond the differences of social class and extend to a cruel racism, sometimes subtle, masked, or even friendly, which seeks through compensatory actions, to erase the feeling of rejection toward blacks (Santos, 2009). As stated by Gomes (2001, p.92): "Racism in Brazil is a complex and singular case, as it is stated by its own negation. He is denied vehemently, but remains present in the system of values that govern the behavior of our society ".

As we shall see, there is a gap between blacks and whites when we think the same opportunities. The myth of racial democracy and the ambiguous racism living Brazilian society often prevent a more open debate on racial inequalities in the country. The expansion of university policies, affirmative action and other policies has contributed to advances in this area. But we still have much to do, challenges to overcome and obstacles to surpass in the search for a more egalitarian and just society in which all identities and 
cultures are equally valued and recognized as part of the formation of Brazilian society.

We started speaking about the black movement in Brazil, as part of the record of struggle and demands of the black population for equal opportunities, recognition of their history and culture, and appreciation of their identity as subjects of rights.

\section{Black Movement and Education: Path of Struggle and Claims}

It can be considered that the black movement in Brazil comes from the history of Africans and their descendants in the Brazilian context, since the trafficking of African people in Brazilian land, that is, since the first acts of struggle and resistance against ill-treatment to which they were subjected. The enslaved blacks never accepted submissively slave labor, neither after the abolition had they expected the white elite to pity their situation. Escapes and the formation of quilombos ${ }^{5}$ undoubtedly represent a radical form of slave resistance against an oppressive and dehumanizing system (Haerter, Nunes \& Cunha, 2013).

But the black movement "is born" and officially takes its first steps into a more organized and representative form after abolition. As mentioned previously, with the enactment of the liberation of the slaves, blacks found themselves completely on the margins of society, with no integration policy aimed at them. From this perspective, women authors and men authors like Gonçalves and Silva (2000), Domingues (2009) and Gomes (2001), point out that schooling becomes of great importance for the black population and the central struggle of the black movement, that has always made the complaint of illiteracy among blacks and sought actions to provide access to education for children and adults, because they understood that schooling would allow social mobility and the appreciation of the black people.

Based on the women authors and men authors cited, the black movement goes through different stages: post-abolition beginning, their concern is focused on the complaint of the present racism in Brazilian society, in the school context and in taking action on basic education; over the years, claims gain a more concrete character and are consolidated in public policies for the black population. 


\section{Gouvêa \& Lima - Affirmative Action}

According to Domingues (2009), the black movement has gone through three phases. In the first phase (1889-1937), post-abolition moment, the movement promoted awareness campaigns among the black population on the importance of literacy; to this end, it opened small schools and literacy courses, in this period the main objective was basic education. In the second phase (1937-1978), the black movement has expanded a little more to its action, in addition to schools and literacy courses, coordinated educational oriented projects, but kept its attention on basic education. The third phase (1978-2003) is characterized by more systematic actions and public policies for the black population. It went on to claim more forcefully a review of the prejudice load in the teaching material and a afro-centered and multicultural education project with inclusive teaching practices and the adoption of African History in the curricula.

Here, we will retain a little more on the phases of the black movement for understanding this movement in the light of the black population in Brazilian society. According to Domingues (2009), the first phase of the black movement, the African-Brazilians were living in a state of social and political exclusion. With regard to education, blacks stayed away from school chairs, or when they had access was with great difficulty. Schools did not accept black children, and when they had the opportunity to be in school, they were so battered that her parents chose to take them away. In response to the racial discrimination they went through, blacks created associations such as clubs, organizations and unions.

According to Domingues (2009), these associations not only stayed in the field of complaint regarding the education of blacks, but created educational and cultural activities in its facilities, such as presentations, theatrical performances, soirées, sessions of poetry recitals, courses and lectures. Some associations have also opened schools: in 1908, Sociedade Amigos da Pátria [Friends of the Country Society], from São Paulo, founded a school and assisted more than 1,000 people. In addition to the state of São Paulo, in other regions of the country, blacks were organized and created schools that sought to assist all individuals regardless of color, gender, nationality, religious belief or profession. Black associations sought to educate the black population of the importance of schooling, as well as the duty with the government. 
Among the associations of the time, Frente Negra Brasileira (1931-1937) [Brazilian Black Front] is highlighted; this association was the one that best organized and developed itself, and was one of the most important within the black movement. It stood out by the number of participants, the achievements and the many activities undertaken. Its political and administrative organization was complex and diverse; it brought together more than sixty delegations distributed throughout the interior of São Paulo and other Brazilian states (Domingues, 2009).

In the first phase of the black movement, we can realize the great attention and concern focused on the education of blacks, because the movement had high expectations in relation to education, since for them the school education had the power to set aside racial prejudice and, ultimately, to eradicate it. "The concept of education articulated by the black movement at this stage was wide, it comprised both schooling and the cultural and moral formation of the individual" (Domingues, 2009, p.973).

In this sense, education transcended to the black movement the act of reading and writing. Access to education meant political power to fight for their rights, for a more just, egalitarian and democratic society. The first phase of the black movement is characterized by the concern to provide access to basic education which made the blacks feel "well, capable, proud of themselves and connected with the grammar of civilization and the modern world" (Domingues, 2009 p.976). This phase was also marked by the ban on all social movements. On December 2, 1937, the national government of Getulio Vargas imposed a decree that considered all movements illegal.

During the New State period, from 1937 to 1945, Brazil experienced a historic moment of great political repression and suppression of democratic rights. As a result, the social movements have suffered from some government actions that made them impossible. This period marks the second phase of the black movement that extends to the year 1978.

During this period some black movements have survived and others have surfaced with more parochial character. In 1943, there is a resurgence of the black movement, through the União dos Homens de Cor (UHC) [Black Men's Union], founded in Porto Alegre; this organization had as its central purpose to raise the economic and intellectual level of the black population throughout the national territory, with the aim of enabling it to join the social 


\section{Gouvêa \& Lima - Affirmative Action}

and administrative life of the country, in all sectors (Domingues, 2009). Based on Domingues (2009), the União dos Homens de Cor claimed the right to free public education or still a quota policy. The association was concerned not only with access, but also the permanence of black people in higher education.

The Teatro Experimental do Negro (TEN) [Blacks Experimental Theatre] was another important group from that stage; established in Rio de Janeiro in 1944, it had Abdias do Nascimento as its main leader. The TEN, in addition to forming a theater group for black people, organized conferences, congresses, beauty contests, opened a research center and a museum. Also it implemented a literacy course and denounced racial prejudice in textbooks. The TEN fulfilled an important role as a coping strategy to color prejudice (Domingues, 2009).

The second phase of the Black Movement maintained the basic education at the center of claims and went further, made the complaint of the teaching material with racist content and went on to fight for higher education. But not yet envisioned multicultural educational practices or systematic forms of educational proposals based on ethnic and racial diversity, or a teaching facing the introduction of African history in the school curricula (Domingues, 2009).

According to Domingues (2009), the third phase of the Brazilian black movement covers the years 1978 to 2003, it was marked by a moment of racism silencing, with the installation of the military dictatorship in 1964. But this did not mean the end of the movement, some voices of the black protest were not silenced and, in the 1970s, they organized the Centro de Cultura e Arte Negra (CECAN) [Center of Black Art and Culture], in São Paulo; the Sociedade de Intercâmbio Brasil-Africa (SINBA) [Brazil-Africa Exchange Society], in Rio de Janeiro; the african block Ilê Aiyê, Bahia.

The political leap only occurred in the late 1970s, with the rise of popular struggles, the trade union, feminist, gay and student movements. A milestone in this process was the birth of the Movimento Unificado Contra a Discriminação Racial (MUCDR) [Unified Movement Against Racial Discrimination] in 1978. Later, its name was changed to Movimento Negro Unificado [Unified Black Movement]; the movement has invested in originating return to African roots as a fundamental element of any political and cultural practice. One of its concerns was to intervene in the educational 
sphere. In 1979, the Núcleo Cultural Afro-Brasileiro [Afro-Brazilian Cultural Center] organized the 1st Seminar on Interethnic Experimental Education.

In the 2nd Seminar on Interethnic Education, a committee was formed that prepared a school curriculum based on black culture. In 1984, the African-Brazilian entities of Bahia were striving to insert in the curricula of public schools disciplines grounded in black history and culture. In the 1980s, several black movement groups emerge again claiming the right to quality education and appreciation of blacks.

In this sense, Gomes (2011) explains that in 1980, Brazil is going through a time of political openness and democratization of society, which enables a new form of performance of black Brazilians. For the author, women and black men started to work more actively in social movements of identity nature, which resulted in another set of questioning and new forms of action and political demand. Gonçalves and Silva (2000) imply that the black movement spent virtually the whole 1980s decade involved with the issues of democratization of education.

According to Gomes (2011), the black movement starts asking "the state, the Brazilian left and the social movements about its neutral and silent positioning on the centrality of race in the country shaping" (Gomes, 2011, p. 111). According to the author, the late 1980s and early 1990s were a period of tensions, criticism and breaks between members of the black movement, the left parties and new social movements' entities, because the movement itself takes a stand of greater political action facing racial inequalities in the country.

From this perspective, we consider that Brazil, in the late twentieth century and early twenty-first century, carried out important actions for the black population. At the end of the 90s and beginning of the following decade, after long debates about affirmative action and quota systems in public universities, the Legislative Assembly of Rio de Janeiro State, in 2002, approved the reserve of $40 \%$ of seats for black students in the entrance exam at the Universidade do Rio de Janeiro (UERJ) [University of Rio de Janeiro] and the Universidade Estadual do Norte Fluminense (Uenf) [State University of Fluminense North]. Another measure of national impact in our country was the enactment of Law No. 10,639, of January 9, 2003, which 
established the mandatory teaching of African and African-Brazilian Culture and History in elementary and high schools.

Based on what was presented, it can be said that the black movement played a key role in actions in favor of the black population and that even today the movement is important in the struggle for equity, overcoming racism and appreciation of the black identity. We turn now to discuss in more detail about the achievements set and gained by the black population in recent years, among them affirmative action, the Secretaria de Educação Continuada, Alfabetização, Diversidade e Inclusão (SECADI) [Department of Continuing Education, Literacy, Diversity and Inclusion] and Law 10,639/03 amending Law 9394/96.

\section{Affirmative Action and Public Policies: an Overview of Achievements for Equal Opportunities in the Brazilian Context}

From what was exposed about the historical context of black struggle and resistance in Brazil, we will pass on to the discussion of the importance of affirmative action and access to education in the country, without omitting ourselves in making a brief explanation of public policy for promoting a more egalitarian society among blacks, indians and whites.

Based on the National Survey by Household Sampling (Brasil, 2015), published by the Brazilian Institute of Geography and Statistics (IBGE), Brazilian population amounts to a total of 201.5 million people who declare their color in $46.1 \%$ white, $53.1 \%$ black (black and brown), and $0.8 \%$ claim to be indigenous or yellow.

Meeting what is presented, the Institute of Applied Economic Research IPEA (2014) provides recent data on the situation of the black population in the Brazilian context that supports the argument that inequalities in Brazil are not guided solely on social disparities, but also racial.

In comparative table of 2001 and 2012, it appears respectively the decrease from $38.1 \%$ to $14.7 \%$ of the black population living with a per capita income of 0.5 minimum wages ${ }^{6}$, while the white population decreased from $17.3 \%$ to $6.2 \%$. When we compare the population living with a per capita income of 1.5 minimum wages, also in 2001 and 2012, it appears that it increases from $27.7 \%$ to $44.9 \%$ the black population living on this income, while the white population number also increases from $39.2 \%$ to $44.9 \%$. 
Based on the data presented, we see a reduction in extreme poverty for both blacks and whites, but that does not mean we reached equity among these groups.

According to IPEA (2014), the change of the economic data over the years was due to the appreciation of minimum wage policies and their impact on the benefits of social security and assistance, for example, the Bolsa Família Program ${ }^{7}$ [Family Assistance Program].

Regarding the educational level, the IPEA (2014) brings net data, explaining the entry and stay of the black population in various educational stages. It is worth emphasizing that even with the entry of more blacks in higher education, yet we have a very low number of this population at the university. In 2001, out of the total population aged 17 and over, the percentage to enter higher education was $14.1 \%$ white and $3.2 \%$ black. In 2012 , the percentage rose to $22.2 \%$ white and $9.6 \%$ black. From the data provided, we can say that higher education begins to open its doors to the black population, but still represents a small percentage compared to the total number of this population in Brazil.

In 2003, Munanga (2003) stated that without public policies or legal measures, even with a supposed improvement in the Brazilian basic education in its quality level, black students would take approximately 32 years to reach the level of white students; furthermore, it would be necessary that the white students stood still in their current positions and waited for the black students to catch up so they could walk together on an equal footing.

From this perspective, it is understood that affirmative actions are key to overcoming inequalities historically accumulated in our context. Such actions are public policies made by the government or by private institutions, with the restorative function of seeking equality between whites, blacks, indigenous and other people or communities who have their rights denied, regarding housing, health, work and education ${ }^{8}$. In this context, the quotas for access to public university are considered affirmative actions.

Currently, federal law No. 12,711/2012 provides that at least the reserve of $50 \%$ of seats in federal public universities is intended for those who have completed high school fully in public schools. Of this amount, 50\% are reserved for students with an income lower or equal to 1.5 minimum wages per capita, and the remainder must be filled by candidates that are selfdeclared blacks, browns and indigenous. 


\section{Gouvêa \& Lima - Affirmative Action}

Note that the reserve of seats for blacks in universities, as a form of affirmative action, still represents tension and disagreements in the academic and social environment. Based on Osorio (2009), there are people who defend social quota claiming that there is a coincidence in attending a public school, being poor and being black, arguing that racial quotas would benefit only blacks and leave aside poor whites. Thus, social quotas would solve social inequality and of class in higher education.

However Osorio (2009) explains that, when considering only racial quotas, the coincidence between race, class and public school studies would be more efficient in the elimination of racial inequalities, understanding through the analyzed data that the black population is in inferior position to whites in all categories analyzed. Thus, it is understood that quotas should be neither only social or only racial, but should comprehend simultaneously the two categories, thinking that the goal is equal access to opportunities in higher education.

In this context, we understand that to overcome the inequalities between blacks and whites in the Brazilian context tireless struggles are made necessary to press the state for public policies, since such policies not only represent the possibility of access to universities, but also the mobility of the black population in different spaces. Accordingly, in tandem with affirmative action, special secretariats, statutes and laws were created over the years, specific to the achievement of equality between blacks and whites.

Currently, we have a Secretariat for the Promotion of Racial Equality Policies (SEPPIR) with Ministry status, created by Provisional Measure No. 111, of March 21, 2003, before the recognition of the struggles of the Brazilian black movement throughout the historical process Exclusion (Brazil, Equality Portal ${ }^{9}$ ).

SEPPIR's main purpose is to formulate, coordinate and articulate public policies and guidelines that promote ethnic and racial equality, understanding that in Brazil there are a lot of communities and people living on the margins of society without access to basic rights such as housing, food and education. Also within this Ministry there are actions addressed to people and traditional communities, that in this concept may be grouped as of African origin communities, maroon, Roma people, and others who have their own "social organization, which occupy and use territories and natural resources as a condition for their cultural, social, religious, ancestral and 
economic reproduction, using knowledge, innovations and practices generated and transmitted by tradition "(Brazil, Equality Portal $\left.{ }^{10}\right)$.

On the educational sphere, we count on the Ministry of Education (MEC), the Department of Continuing Education, Literacy, Diversity and Inclusion (SECADI), which aims to contribute to the development of inclusion by articulating the education systems to the educational policies "focused on appreciation of differences and diversity, the promotion of inclusive education, human rights and environmental sustainability, aiming at the realization of cross-cutting and cross-sectoral public policies "(Brazil, Ministry of Education Portal ${ }^{11}$ ).

Meeting these actions, Brazil advances when we consider current legislation. In 1996, Law No. 9394/1996 was created, regarding Guidelines and Bases of National Education (LDB), this law, in its article 3, section I, ensures "equal footing for access and stay in school." But based on the data presented above, we can say that this does not occur in fact, because the access of black people to education is still low, less expressive when compared to the number of whites in universities, or the illiteracy rate of the two groups.

As mentioned, the black population has always been denied their access to education in different ways. And through social pressures, ongoing struggle and proposals of the black movement, important achievements were obtained in the legislative ${ }^{12}$ framework, in addition to the above: 1) Law No. 10,639/2003 amending Law 9394/1996, establishing the guidelines and bases of national education, to include in the official curricula of the Education Network the mandatory theme "Afro-Brazilian Culture and History"; 2) Law No. 11,645/2008 amending Law No. 9,394/1996, as amended by Law 10,639/2003, which establishes the guidelines and bases of national education, to include in the official curricula of the school system the mandatory theme "Afro-Brazilian and Indigenous Culture and History; 3) Law No. 12,288/2010 establishing the Racial Equality Statute, amending Laws 7,716, of January 5, 1989, 9,029, of April 13, 1995, 7,347 of 24 July, 1985, and 10,778 of November 24, 2003; 4) Law No. 12,711/2012, known as the Law of Quotas, which guarantees reservation of seats in federal institutions of higher education linked to the Ministry of Education (MEC); 5) Law No. 12,990/2014 reserves the blacks $20 \%$ (twenty percent) of the positions offered through public tenders for provision of effective positions 
and public jobs within the federal government scope, local authorities, public foundations, public companies and semi-public companies controlled by the Union.

When thinking about education, it is worth highlighting the performance of the Department for Continuing Education, Literacy, Diversity and Inclusion (SECADI) among their actions for the implementation of Law 10,639 and programs development, it made possible management processes, continuing education courses, distribution of paradidactic materials and researches (Gomes, 2011).

Based on Gomes and Jesus (2013), from the 2000s, Brazil went on to form a set of legal provisions that led to a focused educational policy for the assertion of cultural diversity and implementation of an education for ethnic and racial relations. According to the authors, the amendment of the LDB by Law 10,639/03, the CNE/CP1/2004 resolution, that defines the National Curricular Guidelines for the Education of Racial-Ethnic Relations and the Teaching of African and African-Brazilian Culture and History, based on the verdict CNE/CP 3/2004, in accordance with its legislation and its provisions can be regarded as central to the process of implementation of affirmative action policies in Brazilian education at different levels, stages and educational modalities .

From this perspective, we believe that Brazil in response to the proposals of the black movement, social pressures and other Allied agents of the antiracist struggle, has taken important steps to meet the demands of the population. The affirmative action policies represent the realization of claims of long years of struggle for health conditions, education, housing and a decent life to black people.

As indicated by Maio and Santos (2005):

In the most diverse spheres of Brazilian society, whether on the issue of education, health or socio-economic conditions, it is clear that there are inequities in the ethnic-racial grounds that need to be tackled. The fight against racism has occupied a prominent place in contemporary political debate. If there is agreement as to the existence and relevance of the problem, the crux of the debate focuses on ways of tackling it (p.207) 
In this sense, many achievements have been made, demands were met both on the legislative and on the education sphere, but we are still far from a more egalitarian society between blacks and whites. We believe that "if education alone does not transform society, without it neither does society change" (Freire, 2000, p.67), in that sense, "it inflicts the review of the role of education that not being the doer of everything, it is a key factor in reinventing the world" (Freire, 2001, p.10). Therefore, ensuring quality education as well as access and stay of all people, regardless of race, class, gender and culture, is the possibility of a more just and egalitarian society in which all people can live and have their choices respected.

\section{Final Considerations}

Based on the studies of Gomes (2011), we consider that the adoption of affirmative action policies such as Law 10,639/03 and its Curricula Guidelines for the Education of Racial-Ethnic Relations and for the teaching of African and Afro-Brazilian History as well as a reservation for blacks in the universities "clash with the practices and racial imagery present in the structure and functioning of Brazilian education, such as the myth of racial democracy, ambiguous racism, the whitening ideology and the naturalization of racial inequalities "(Gomes, 2011, p.116).

As indicated by Gomes (2011), we must understand that these achievements do not mean a state gift, but as we have seen throughout the text, it represents the fruit of a social struggle process, denied rights and the black movement's claims requiring as a State duty the recognition and legitimation of the race issue in public policies of health, labor, environment, land, youth, gender (Gomes, 2011).

Therefore, the imposition of these policies leads the Brazilian people to look at themselves and the contradiction they live when denying racism and at the same time, keeping visible inequalities between blacks and whites. Brazilian society has achieved concrete actions in favor of the black population, but we are still far from canceling out racial and social inequalities present in our context. Quoting Freire (2000), "world change implies the dialectization between the denunciation of the dehumanizing situation and the announcement of its overcoming deep down, our dream. (...) Changing is hard but possible " (p.81). In this sense, the demand of the 
State is important, but the action of each individual in the world and with others is key to overcoming or, at least minimizing the racial and social inequalities.

\section{Notes}

${ }^{1}$ The term race is used and understood here as a social construct and a political positioning. The Black Movement and several scholars in the field of race relations in Brazil make use of the term with a social and political sense related to the history of blacks in Brazil and the complex relationship between race, racism, prejudice and racial discrimination (Munanga \& Gomes, 2006).

${ }^{2}$ As we consider the equality of differences, we do not disregard the indigenous peoples who also live on the margins of our society. This portion of the population, alike the blacks, has their struggles and follows in pursuit of public policies in their favor.

${ }^{3}$ Brazil was the last country in the West to free the black population from slavery. From the beginning of the slave trade in the sixteenth century to its end in the nineteenth century, were brought from Africa about 9.5 million blacks to the Americas. From these, most were intended to Brazil, which imported thirty-eight percent of the total, being the rest sent to other countries (Ianni, 2004).

${ }^{4}$ It is worth mentioning that when we use the masculine form - black and white, we are not ignoring the black and white women.

(t.n) In Portuguese language, the words black and white carry the masculine suffix "o", although they correspond to men and women.

${ }^{5}$ Quilombos can be understood as political projects and freedom groups, spaces where relatively autonomous societies were recreated and with a strong presence in African traditions. It was certainly one of the most radical forms of resistance to the Brazilian slave system and meant reframing space of culture and ways of life, bringing together elements from different cultures, such as African, indigenous and other groups dissatisfied with the reality of the time. Quilombos were places where former slaves were the protagonists of their stories. The Quilombo de Palmares is highlighted in the history of Brazil, he remained alive for almost the entire seventeenth century and had over twenty thousand people, among Africans, Africans and their descendants, as well as other groups. It was led by Zumbi dos Palmares, now regarded as a symbol of struggle and resistance for the black population and the Brazilian history (Haerter, Nunes \& Cunha, 2013). Note that the November 20, day of Zumbi's death was established as National Black Consciousness Day.

${ }^{6}$ It is noteworthy that the current minimum wage is U\$202.80.

(t.n) This amount corresponds to $\mathrm{R} \$ 788,00$ (Brazilian currency). 
${ }^{7}$ The Bolsa Família is a direct transfer program income that benefits families in poverty and extreme poverty throughout the country. The Bolsa Família integrates the Brazil Without Poverty Plan, whose operations focus on the millions of Brazilians with a per capita income below U\$ 19.85 per month and is based on guaranteed income, productive inclusion and access to public services (http: //www.mds.gov.br/bolsafamilia).

(t.n) U\$ 19.85 corresponds to R 77.00 (Brazilian currency).

${ }^{8} \mathrm{http}: / /$ www.portaldaigualdade.gov.br/assuntos/o-que-sao-acoes-afirmativas

${ }^{9}$ http://www.portaldaigualdade.gov.br/sobre-a-seppir/o-ministerio

10 http://www.portaldaigualdade.gov.br/sobre/perguntas-frequentes

11

http://portal.mec.gov.br/index.php?option=com_content \&view=article\&id=290\&Itemid=816

12 The laws cited in this paragraph are available for public access and are included in the references of this article respectively as: 1) Brasil, 2004a; 2) Brasil, 2008; 3 ) Brasil, 2010; 4) Brasil, 2012; 5) Brasil, 2014.

\section{References}

Brasil. (2004a). Diretrizes Curriculares Nacionais para a Educação das Relações Étnico-Raciais e para o Ensino De História e Cultura AfroBrasileira e Africana. Brasília. DF. Retrieved from http://www.acaoeducativa.org.br/fdh/wp-content/uploads/2012/10/DCNs-Educacao-das-Relacoes-Etnico-Raciais.pdf

Brasil. (2004b). [Lei de Diretrizes e Bases da Educação Nacional (1996)] LDB: Lei de Diretrizes e Bases da Educação:(Lei 9.394/96) e legislação correlata / Coordenação André Arruda. - Rio de Janeiro: Roma Victor. Retrieved from http://www.planalto.gov.br/ccivil_03/Leis/L9394.htm Brasil. (2008). Lei $n^{o} 11.645$, de 10 de março de 2008. República Federativa do Brasil: Poder Legislativo, Brasília-DF. Retrieved from http://www.planalto.gov.br/ccivil_03/_ato20072010/2008/lei/111645.htm

Brasil. (2010). Lei $n^{\circ} 12.288$, de 20 de julho de 2010. República Federativa do Brasil: Poder Legislativo, Brasília- DF. Retrieved from http://www.planalto.gov.br/ccivil_03/_Ato20072010/2010/Lei/L12288.htm\#art60

Brasil. (2012). Lei $n^{\circ} 12.711$, de 29 de agosto de 2012. República Federativa do Brasil: Poder Legislativo, Brasília-DF. Retrieved from 
http://www.planalto.gov.br/ccivil_03/_ato2011-

2014/2012/lei/112711.htm

Brasil. (2014). Lei $n^{\circ}$ 12.990, de 9 de junho de 2014. República Federativa do Brasil: Poder Legislativo, Brasília-DF. Retrieved from

http://www.planalto.gov.br/ccivil_03/_Ato2011-

2014/2014/Lei/L12990.htm

Brasil. (2015). Pesquisa Nacional por Amostra de Domicílios Estudos.

Síntese de indicadores sociais - uma análise das condições de vida da população brasileira - 2013. IBGE - Instituto Brasileiro de Geografia e Estatística. Retrieved from http://biblioteca.ibge.gov.br/visualizacao/livros/liv94414.pdf

Cavalleiro, E. (2000). Do silêncio do lar ao silêncio escolar-racismo, preconceito e discriminação na educação infantil. São Paulo, Contexto. Cunha Jr. (2008). Abolição inacabada e a educação dos afrodescendentes. Revista Espaço Acadêmico, nº 89.

Retrieved from http://www.espacoacademico.com.br/089/89cunhajr.pdf

Domingues, P. J. (2002). Negros de Almas Brancas? A ideologia do branqueamento no interior da comunidade negra em São Paulo, 19151930. Estudos Afro-Asiáticos, 24(3), 563-599. Retrieved from http://www.scielo.br/pdf/eaa/v24n3/a06v24n3

Domingues, P. J. (2009). O recinto sagrado: educação e antirracismo no Brasil. Cadernos de Pesquisa, 39(138), 963-994. Retrieved from http://www.scielo.br/pdf/cp/v39n138/v39n138a14.pdf

Freire, P. (2001). Política e educação. Coleção Questões da Nossa Época, V. 23, 5. ed - São Paulo, Cortez.

Gomes, N. L. (2001). Educação cidadã, etnia e raça: o trato pedagógico da diversidade. In: Racismo e anti- racismo na educação: repensando nossa escola /Eliane Cavalleiro (Organizadora). São Paulo: Selo Negro. 8396.

Gomes, N. L. (2008). Sem perder a raiz: corpo e cabelo como símbolos da identidade negra. $2^{\mathrm{a}}$ ed. - Belo Horizonte: Autêntica. 
Gomes, N. L. (2009). In: Negritude: usos e sentidos. Kabengele Munanga Belo Horizonte: Autêntica Editora - (Coleção Cultura Negra e Identidades).

Gomes, N. L. (2011). Diversidade étnico-racial, inclusão e equidade na educação brasileira: desafios, políticas e práticas. $R B P A E, 27(1), 109$ 121. Retrieved from http://seer.ufrgs.br/rbpae/article/viewFile/19971/11602

Gomes, N. L. \& Jesus, R. E. de (2013). As práticas pedagógicas de trabalho com as relaçoes étnico-racias na perspectiva de Lei 10.639/2003:desafios para a política educacional e indagações para a pesquisa. Educar em Revista, Curitiba, Brasil, 47. Editora UFPR. 19-33. Retrieved from http://www.scielo.br/pdf/er/n47/03.pdf

Gonçalves, O. A. L \& Silva, G. B. P. (2000). Movimento Negro e educação. Revista Brasileira de Educação, nº 15, p.134-158. Set/Out/Nov/Dez . Retrieved from http://www.scielo.br/pdf/rbedu/n15/n15a09.pdf

Haerter, L., Nunes, G. H. L. \& Cunha, D. T. R. (2013). Refletindo acerca da contribuição da cultura quilombola aos currículos da educação básica brasileira, através da história da presença da história da África e AfroBrasileira. Identidade, vol.18, $\mathrm{n}^{\mathrm{o}} 3$. Retrieved from http://periodicos.est.edu.br/index.php/identidade/article/view/1175 IPEA. (2014). Situação social da população negra por estado / Instituto de Pesquisa Econômica Aplicada; Secretaria de Políticas de Promoção da Igualdade Racial. - Brasília : IPEA, 2014. Retrieved from http://www.ipea.gov.br/portal/images/stories/PDFs/livros/livros/livro_sit uacao-social-populacao-negra.pdf

Ianni, O. (2004). Raças e classes sociais no Brasil. São Paulo: Brasiliense. Maciel, C. S. (1985) Discriminações raciais: negros em Campinas (18881926) alguns aspectos. Dissertação de Mestrado. Departamento de História. Instituto de Filosofia e Ciências Humanas. UNICAMP. Maio, M.C. \& Santos, R.V. (2005). Política de cotas Raciais, os "olhos da sociedade" e os usos da antropologia: O caso do vestibular da Universidade de Brasília (UNB). Horizontes Antropológicos, Porto 
Alegre, 11(23), 181-214. Retrieved from http://www.scielo.br/pdf/ha/v11n23/a11v1123.pdf

Moehleck, S. (2002). Ação afirmativa: história e debates no Brasil.

Cadernos de Pesquisa, 117, 197-217. Retrieved from http://www.scielo.br/pdf/cp/n117/15559.pdf

Munanga, K. (2003). Política de ação afirmativa em benefício da população negra no Brasil: um ponto de vista em defesa de cotas. In: Educação e Ações Afirmativas; entre a injustiça simbólica e a injustiça econômica. Brasília, INEP. 115-128.

Munanga, K. (2006). Rediscutindo a mestiçagem no Brasil-Identidade nacional versus identidade negra. - $2^{\mathrm{a}}$ ed., 1reimp. - Belo Horizonte: Autêntica.

Munanga, K. \& Gomes N. L. (2006). O negro no Brasil de hoje. São Paulo: Global. (Coleção para entender).

Oliveira, I. M. A.(2008). A ideologia do branqueamento na sociedade brasileira. Secretaria do Estado do Paraná.Universidade Estadual do Norte do Paraná. Paraná. Retrieved from http://www.diaadiaeducacao.pr.gov.br/portals/pde/arquivos/1454-6.pdf

Osório, R. G. (2009). Classe, raça e acesso ao Ensino Superior no Brasil. Cadernos de Pesquisa, 39(138), 867-890. Retrieved from http://www.scielo.br/pdf/cp/v39n138/v39n138a09.pdf

Piovisan, F. (2005) Ações afirmativas da perspectiva dos direitos humanos. Cadernos de Pesquisa. São Paulo, 35(124), 43-55. Retrieved from http://www.scielo.br/pdf/cp/v35n124/a0435124.pdf

Santos, G. (2009). Relações raciais e desigualdade no Brasil. São Paulo:

Selo Negro (Consciência em debate / coordenada por Vera Lúcia Benedito). 
Daniela Mara Gouvêa Bellini: NIASE/ Universidade Federal de São Carlos (Brazil).

Dra . Francisca de Lima Constantino: NIASE/ Universidade Federal de São Carlos (Brazil).

Contact Address: Rod. Washington Luis - km 235, São Carlos SP/Brazil - CEP: 13565-905 